\title{
Identification and characterization of a novel thermostable pyrethroid-hydrolyzing enzyme isolated through metagenomic approach
}

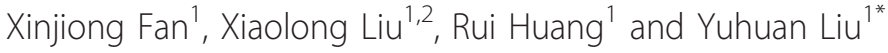

\begin{abstract}
Background: Pyrethroid pesticides are broad-spectrum pest control agents in agricultural production. Both agricultural and residential usage is continuing to grow, leading to the development of insecticide resistance in the pest and toxic effects on a number of nontarget organisms. Thus, it is necessary to hunt suitable enzymes including hydrolases for degrading pesticide residues, which is an efficient "green" solution to biodegrade polluting chemicals. Although many pyrethroid esterases have consistently been purified and characterized from various resources including metagenomes and organisms, the thermostable pyrethroid esterases have not been reported up to the present.

Results: In this study, we identified a novel pyrethroid-hydrolyzing enzyme Sys410 belonging to family $\mathrm{V}$ esterases/ lipases with activity-based functional screening from Turban Basin metagenomic library. Sys410 contained 280 amino acids with a predicted molecular mass (Mr) of $30.8 \mathrm{kDa}$ and was overexpressed in Escherichia coli BL21 (DE3) in soluble form. The optimum pH and temperature of the recombinant Sys 410 were 6.5 and $55^{\circ} \mathrm{C}$, respectively. The enzyme was stable in the $\mathrm{pH}$ range of $4.5-8.5$ and at temperatures below $50^{\circ} \mathrm{C}$. The activity of Sys 410 decreased a little when stored at $4^{\circ} \mathrm{C}$ for 10 weeks, and the residual activity reached $94.1 \%$. Even after incubation at $25^{\circ} \mathrm{C}$ for 10 weeks, it kept $68.3 \%$ of its activity. The recombinant Sys 410 could hydrolyze a wide range of $\rho$-nitrophenyl esters, but its best substrate is $\rho$-nitrophenyl acetate with the highest activity $(772.9 \mathrm{U} / \mathrm{mg})$. The enzyme efficiently degraded cyhalothrin, cypermethrin, sumicidin, and deltamethrin under assay conditions of $37^{\circ} \mathrm{C}$ for 15 min, with exceeding $95 \%$ hydrolysis rate.
\end{abstract}

Conclusion: This is the first report to construct metagenomic libraries from Turban Basin to obtain the thermostable pyrethroid-hydrolyzing enzyme. The recombinant Sys410 with broad substrate specificities and high activity was the most thermostable one of the pyrethroid-hydrolyzing esterases studied before, which made it an ideal candidate for the detoxification of pyrethroids.

Keywords: Metagenomic library, Esterase, Pyrethroid, Thermostable, Turban basin

\section{Background}

Pyrethroid pesticides are synthetic analogues of pyrethrins, which are natural chemicals derived from Chrysanthemum flowers [1]. They are also used as broadspectrum pest control agents in agricultural production, thanks to their high toxicities to insects and low toxicities to mammals [2]. Currently, organophosphorous

\footnotetext{
* Correspondence: Isslyh@mail.sysu.edu.cn

'School of life sciences, Sun Yat-sen University, Guangzhou 510275, P. R. China

Full list of author information is available at the end of the article
}

pesticides are increasingly being replaced by pyrethroid pesticides, and the impact of the pyrethroid pesticides residual on the environment is likely to draw more attention [3,4]. Both agricultural and residential usage is continuing to grow [5], leading to the development of insecticide resistance in the pest and toxic effects on a number of nontarget organisms, such as man, fish and bees [6-8].

Current disposal methods for pesticides residual are both abiotic and biotic pathways, including photooxidation, chemical oxidation and biodegradation. Moreover,
C Biomed Central

() 2012 Fan et al; licensee BioMed Central Ltd. This is an Open Access article distributed under the terms of the Creative Commons Attribution License (http://creativecommons.org/licenses/by/2.0), which permits unrestricted use, distribution, and reproduction in any medium, provided the original work is properly cited. 
enzymes can offer an efficient "green" solution to biodegrade polluting chemicals, thereby playing pivotal roles in the field of bioremediation [9]. Thus, it is necessary to hunt suitable enzymes including hydrolases for degrading pesticide residues [10-12].

Esterases, a generic term for a hydrolase that catalyzes the cleavage and formation of ester bonds, play a major role in the degradation of natural compounds and industrial pollutants, and thus dominate the industrial market for the food, medicine, biodiesel, and agricultural industries with attractive features $[13,14]$. Some pyrethroid esterases have consistently been purified and characterized from various resources including metagenomes and organisms [12,15-18]. To date, the thermostable pyrethroid esterases have not been reported.

Thermotolerant or thermophilic microorganisms are a valuable source of thermostable enzymes often associated with stability in solvents and detergents, giving these enzymes considerable potential applications in many industries $[19,20]$. An approach to obtain novel, efficient and thermostable enzymes from natural resources is gaining momentum. The use of metagenomics, a culture-independent technique [21-23], does not require the cultivation of diverse microorganisms from environmental samples, which is often difficult or impossible. This maximizes our chances to obtain ideal biocatalysts, such as lipases and esterases [24-29]. The Turban Basin, the hottest area in China, has attracted the attention of scholars and scientists with its unique position. The average temperature in summer is beyond $38^{\circ} \mathrm{C}$ and, interestingly, land surface temperature is more than $82^{\circ} \mathrm{C}$ for a certain period. Therefore, most of the enzymes released by natural microorganisms in Turban Basin possess thermostable characteristics.

In order to obtain novel thermostable pyrethroidhydrolyzing enzyme that share low or moderate homology with other known counterparts, we constructed metagenomic library from Turban Basin soil by functional expression screening of plasmid clones with esterase activity. Three clones with esterase activity were detected, but only one novel thermostable pyrethroidhydrolyzing enzyme was selected for further characterization including thermal stability, substrate specificity and degradation efficiency. To our knowledge, this is the first report so far on information about thermostable pyrethroid-hydrolyzing enzyme gene from the unculturable bacterial genome. Further study is helpful to obtain excellent detoxifying enzyme for bioremediation.

\section{Results}

\section{Screening for pyrethroid-hydrolyzing esterases from a} metagenomic library

The total DNA for metagenomic library was extracted from Turban Basin soil. Approximately 21,000 cells of
Escherichia coli (E. coli) TOP10 containing the pUC118based metagenomic DNA library were prepared. The average insert size was $4.8 \mathrm{~kb}$, and sizes ranged from 2.5 to $10 \mathrm{~kb}$. The metagenomic library represented about $100 \mathrm{Mb}$ of soil microbial community DNA. Out of approximately 21,000 colonies, 3 clones were identified by their bright blue color. There was only one positive blue colony E. coli TOP10 (pUC3) with the ability to hydrolyze pyrethroids confirmed by gas chromatography analysis. Therefore, pUC3 was selected to further research.

\section{Genetic characterization}

The fragment size in plasmid pUC3 was $3.936 \mathrm{~kb}$. The sequence analysis of the insert DNA showed the presence of one open reading frame (ORF) $843 \mathrm{bp}$, encoding a polypeptide of 280 amino acids with a predicted molecular mass $(\mathrm{Mr})$ of $30.8 \mathrm{kDa}$. The putative esterase gene was designated sys 410 .

The putative amino acid sequence of Sys 410 was used to perform a BLAST program provided by the National Centre for Biotechnology Information and Swissprot databases. This search showed the moderate identity between Sys410 and other esterases/lipases, the highest with alpha/beta hydrolase fold family protein Brevundimonas diminuta ATCC 11568 (200/265, 75\% identity). Multiple sequence alignment of Sys410 and other lipase/ esterase proteins revealed the typical catalytic triad of active site serine (S102) motif G-X-S-X-G (Figure 1), conserved aspartic acid (D226), and histidine (H260) residue motif in the encoded protein [13,30]. Bacterial lipase/esterase proteins have been classified into eight different families on the basis of their amino acid sequences and biochemical properties [31]. A phylogenetic tree was constructed to further verify the evolutionary relationship among Sys410 and other known lipase/esterase proteins [28]. These results suggested that Sys410 belongs to familyV (Figure 2).

\section{Heterologous expression and purification of recombinant Sys410}

The full-length sys 410 gene was amplified and cloned into the expression vector pET-28a (+) with a C-terminal $6 \times$ His tag, and expressed in E. coli BL21 (DE3) with $0.6 \mathrm{mM}$ IPTG induction at $37^{\circ} \mathrm{C}$ for $8 \mathrm{~h}$, then purified by Ni-NTA-agarose chromatography. The target recombination protein appeared as a single band on SDS-PAGE with molecular weight $36.7 \mathrm{kDa}$ (Figure 3), consist of the 280 amino acids with a fusion of 54 amino acids corresponding to polyhistidine tag (Histag), a unique thrombin cleavage site (Thrombin). The highest expression level of Sys410 $\left(\mathrm{OD}_{600}=3.8\right)$ was about $0.24 \mathrm{mg} / \mathrm{mL}$ and its content in total soluble protein reached up to $50 \%$ according to Quantity One 


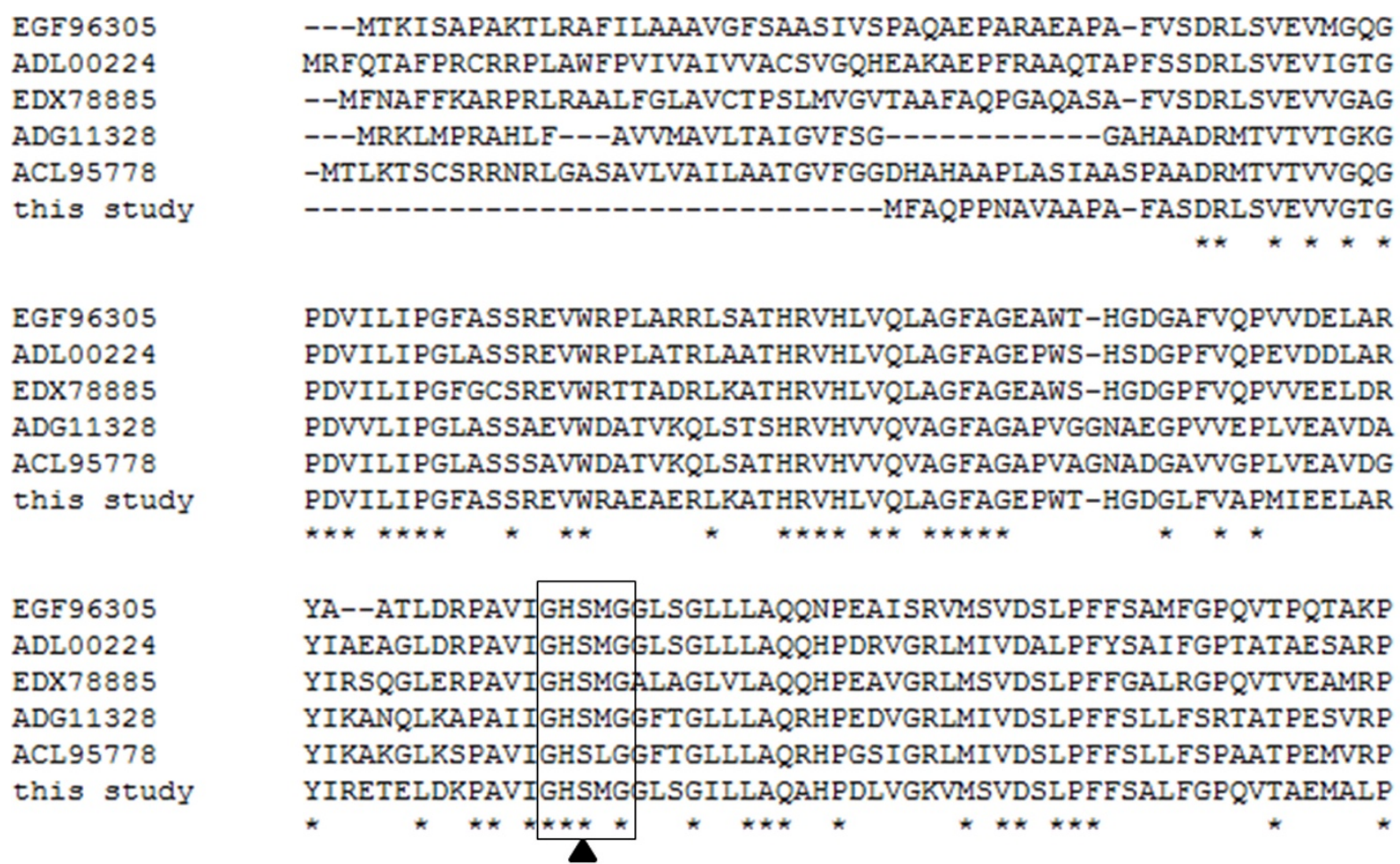

---MTKISAPAKTLRAFILAAAVGFSAASIVSPAQAE PARAEAPA-FVSDRLSVEVMGQG MRFQTAFPRCRRPLAWFPVIVAIVVACSVGQHEAKAEPFRAAQTAPFSSDRLSVEVIGTG --MFNAFFKARPRLRAALFGLAVCTPSLMVGVTAAFAQPGAQASA-FVSDRLSVEVVGAG ---MRKLMPRAHLF---AVVMAVLTAIGVFSG-------------GAHAADRMTVTVTGKG -MTLKTSCSRRNRLGASAVLVAILAATGVFGGDHAHAAPLASIAASPAADRMTVTVVGQG ------------------------------MFAQPPNAVAAPA-FASDRLSVEVVGTG $\star \star \star * * * *$

PDVILIPGFASSREVWRPLARRLSATHRVHLVQLAGFAGEAWT-HGDGAFVQPVVDELAR PDVILIPGLASSREVWRPLATRLAATHRVHLVQLAGFAGEPWS-HSDGPFVQPEVDDLAR PDVILIPGFGCSREVWRTTADRLKATHRVHLVQLAGFAGEAWS-HGDGPFVQPVVEELDR PDVVLIPGLASSAEVWDATVKQLSTSHRVHVVQVAGFAGAPVGGNAEGPVVEPLVEAVDA PDVILIPGLASSSAVWDATVKQLSATHRVHVVQVAGFAGAPVAGNADGAVVGPLVEAVDG PDVILIPGFASSREVWRAEAERLKATHRVHLVQLAGFAGE PWT-HGDGLFVAPMIEELAR

YA--ATLDRPAVI GHSMGGLSGLLLAQNPEAISRVMSVDSLPFFSAMFGPQVTPQTAKP YIAEAGLDRPAVIGHSMGGLSGLLLAQQHPDRVGRLMIVDALPFYSAIFGPTATAESARP YIRSQGLERPAVI GHSMGALAGLVLAQQHPEAVGRLMSVDSLPFFGALRGPQVTVEAMRP YIKANQLKAPAI I GHSMGGFT GLLIAQRHPEDVGRLMIVDSLPFFSLLFSRTAT PESVRP YIKAKGLKSPAVI GHSLGGFTGLLIAQRHPGSIGRLMIVDSLPFFSLLFSPAATPEMVRP YIRETELDKPAVIGHSMGELSGILLAQAHPDLVGKVMSVDSLPFFSALFGPQVTAEMALP

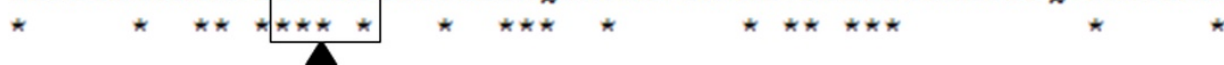

FADQAAASILNADEAAFRIQQERTAVGMMRDEAGAAMVDWSMASNRQAMASAIREVMTT FAARFASGMLAADDAT FRSQQAQSAMGLARDPAMRETMVAWSMASDRQALAAALTDVMTT AAEQTAQTLLALSDESFRAAQVGSAQGMTRDAALRVRLVDWTTGSDRKAMAAAMRDVLLT QAAAMRDATVAMSAENFASQQAMAAPRYVKSPEGQALMLAWSKASSQSVVGRAMYDLLTT QAVQMRDATVAMSPEAFAGQQAMGAPRFVKSAEGQKQVIAWGGASSPSVVGRAMYDLLVT FADQAAQSMLNPDADAFRAGQAQSAVGLARDPATRTAMVDWSMASDRQALASAIREVMTT

DARPGLAAMTT PVWAVYASDADGGAPAAMADALWSREYAALSGVTLKRVDGARHFIMVDQ DARPGLANMATPVTAVYAIDADGGPPPAMAQGLWTQEYASLPGVTLIAVDGSAHFIMADQ DARPGLANLSVPVTALYASDADGGAPAAQADQAWGHEYATLPGVKLIRVDGSRHFIMADQ DARSGLAGVKAPTTLLYP DDAMGAPVTMIEKIYADAYAGLPAVALKRVDDSRHFIMLDQ DARGDLAKVKAPTTLLYAYDIFMGMPSTAADRLFVDAYAGLPGLKATRIDDARHFIMLDQ DARPALATMTT PVWAIYASDADGGAPAAMADALWTREYATLPGVHLERVDDSRHFIMADQ

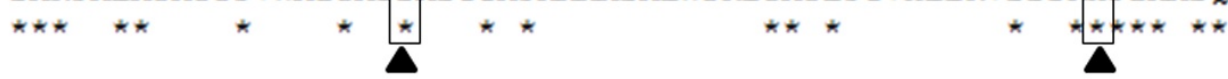
PDRLDALVDAFLESED
PARFDQLVDDFLK---
PQRFAELVDQFLAD--
PKAFADAVEVFLK---
PQAFAQAVADFLK---
PQRFAAVVDRFLAE--

Figure 1 Multiple amino acid sequence alignment of Sys410. Multiple alignment of the partial Amino acid sequences containing the conserved motifs of $\mathrm{G} \times \mathrm{S} \times \mathrm{G}$ and putative catalytic triad resides of alpha/beta hydrolase family proteins. Except for Sys410 (this study), other protein sequences were retrieved from GenBank http://www.ncbi.nlm.nih.gov. The accession numbers of the aligned sequences are for the following organisms: EGF96305, alpha/beta hydrolase fold family protein from Brevundimonas diminuta ATCC 11568; ADL00224, alpha/beta hydrolase fold protein from Brevundimonas subvibrioides ATCC 15264; EDX78885, hydrolase, alpha/beta fold family from Brevundimonas sp. BAL3; ADG11328, alpha/beta hydrolase fold protein from Caulobacter segnis ATCC 21756; ACL95778, alpha/beta hydrolase-family protein from Caulobacter crescentus NA1000. The alignment was carried out using the Clustal W method. The open boxes indicate amino acid resides belonging to the putative catalytic triad resides, triangles denote the active site. The same amino acid resides are marked by $\left(^{*}\right)$. 


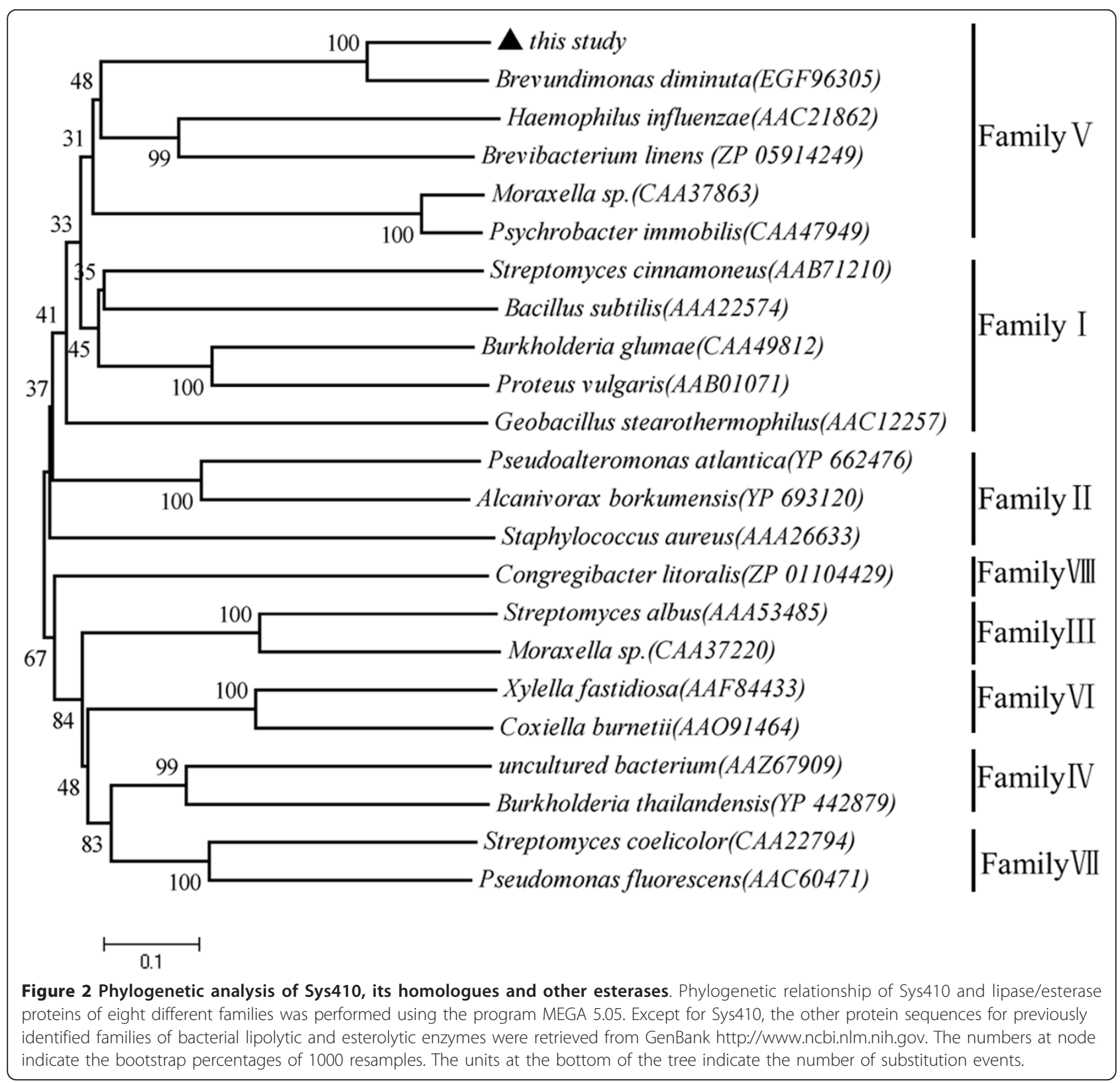

software (Bio-Rad laboratories Inc., Hercules, USA) for protein band visualization.

Effect of pH and temperature on Sys410 activity and stability

The effect of $\mathrm{pH}$ over purified Sys410 activity was determined using $\rho$-nitrophenyl acetate as a substrate at $40^{\circ}$ C. Sys410 displayed high activity at $\mathrm{pH}$ values between 5.0 and 7.5, and optimal pH is 6.5 (Figure 4). The pH stability was tested after incubation of purified Sys410 in various buffers at $\mathrm{pH} 3.5$ to 10.0 . After $24 \mathrm{~h}$ incubation, Sys410 displayed more than $80 \%$ residual activity in the
$\mathrm{pH}$ range 5.0 to 8.0 . $\mathrm{pH}$ stability was therefore concluded to be greatest at $\mathrm{pH} 6.5$.

The effect of temperature over purified Sys410 activity was made using $\rho$-nitrophenyl acetate as a substrate at $\mathrm{pH}$ 6.5, with temperatures ranging from 20 to $80^{\circ} \mathrm{C}$. Esterase activity increased as temperature increased up to $55^{\circ} \mathrm{C}$, and decreased beyond that level. At temperatures above $80^{\circ} \mathrm{C}$, there was essentially little enzyme activity. The optimal temperature was $55^{\circ} \mathrm{C}$ (Figure 5). Thermostability was determined by analysis of residual activity at regular intervals after preincubation for durations up to $12 \mathrm{~h}$, at temperatures ranging from $35-60^{\circ} \mathrm{C}$. 


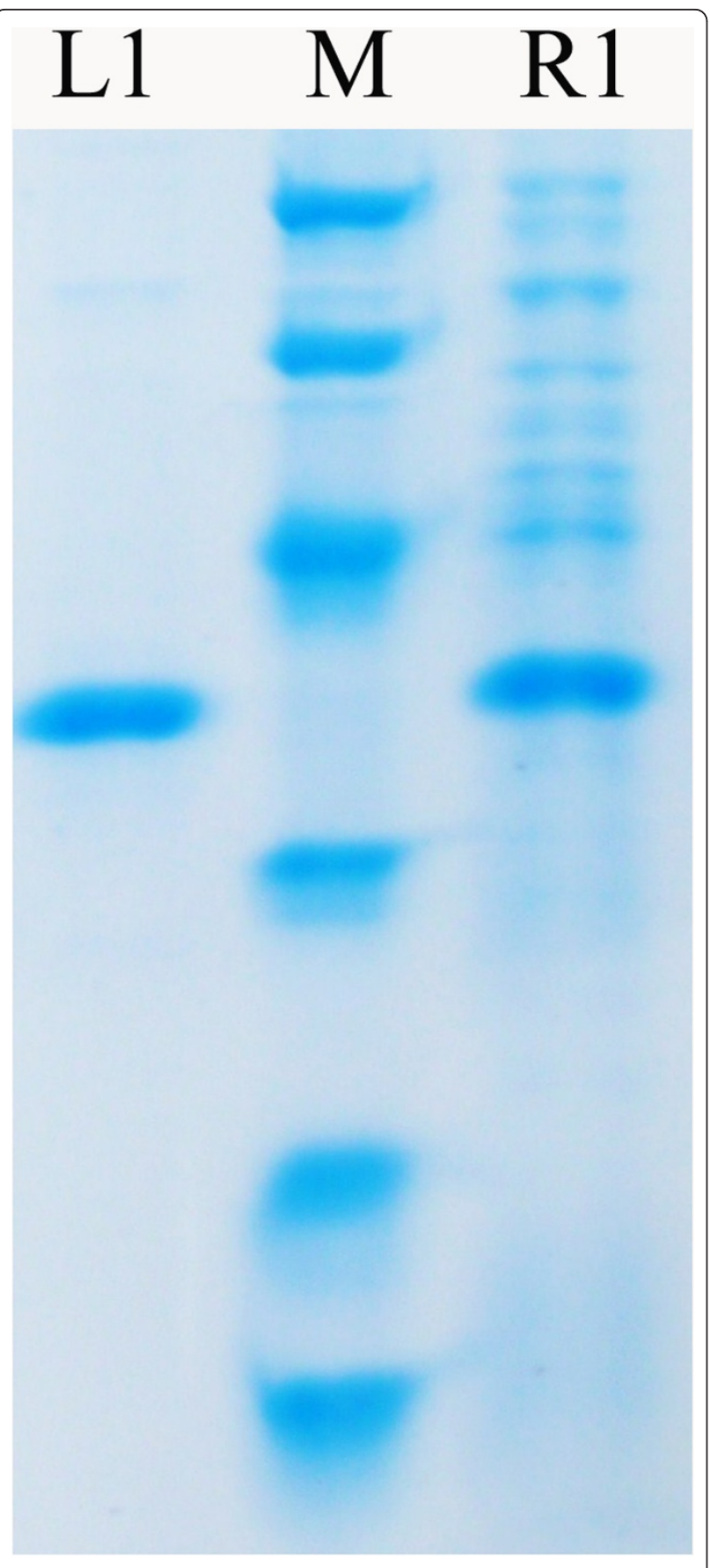

Figure 3 SDS-PAGE analysis of the purified recombinant Sys410. Purified target protein (lane L1); supernatant of E. coli BL21 (DE3) cell lysates (lane R1); protein markers (lane M) stained with Coomassie blue, with the list from top to bottom $97.2 \mathrm{kDa}$, 66.4 $\mathrm{kDa}, 44.3 \mathrm{kDa}, 29.0 \mathrm{kDa}, 20.1 \mathrm{kDa}, 14.3 \mathrm{kDa}$.

Sys 410 was very stable below $45^{\circ} \mathrm{C}$, with residual activity exceeding 85\% after incubation for $12 \mathrm{~h}$ (Figure 5).

The storage stability of the recombinant enzyme was determined at $4^{\circ} \mathrm{C}$ and $25^{\circ} \mathrm{C}$ for 10 weeks (Figure 6). Esterase activity decreased a little when stored in 50
$\mathrm{mM}$ potassium phosphate buffer $(\mathrm{pH} 6.5)$ at $4^{\circ} \mathrm{C}$ for 10 weeks, and the residual activity reached $94.1 \%$. Sys 410 kept $68.3 \%$ of its activity after incubation at $25^{\circ} \mathrm{C}$ for 10 weeks.

\section{Substrate specificity and activity of Sys410}

To determine the substrate specificity of Sys410, we tested its activity on various $\rho$-nitrophenyl esters with acyl chain lengths of $\mathrm{C} 2, \mathrm{C} 4, \mathrm{C} 6, \mathrm{C} 8, \mathrm{C} 10$, and $\mathrm{C} 12$ under assay conditions of $\mathrm{pH} 6.5$ and $55^{\circ} \mathrm{C}$. Recombinant Sys410 showed the highest activity with $\rho$-nitrophenyl acetate $(772.9 \mathrm{U} / \mathrm{mg})$ among the $\rho$-nitrophenyl esters examined, low levels of activity toward $\rho$-nitrophenyl esters with long acyl groups (Table 1 ). The $K \mathrm{~m}$ and $k_{\text {cat }}$ values were calculated by fitting the data to Michaelis-Menten equation. Moreover, when acyl chain lengths were $\mathrm{C} 2$, its $k_{\text {cat }}$ and $K \mathrm{~m}$ values were $289.1 \mathrm{~S}^{-1}$ and $14.1 \mu \mathrm{M}$, respectively. When acyl chain lengths were between 4 and 12 , its $k_{\text {cat }}$ values decreased, while $K \mathrm{~m}$ values rose with acyl chain length rising.

The degradation efficiency by Sys410 was tested with four different pyrethroids as the substrates by gas chromatography analysis (Figure 7). The hydrolysis rates of cyhalothrin, cypermethrin, sumicidin and deltamethrin were $98.1 \%$, 99.7\%, 97.1\%, 95.8\%, respectively, under assay conditions of $\mathrm{pH} 6.5$ and $37^{\circ} \mathrm{C}$ for $15 \mathrm{~min}$.

\section{Discussion}

Soil mainly reserves abundant microbial diversity on the earth [32]. According to reports, more than 99\% microorganisms can not be cultured [33-37]. Fortunately, the number of potential biocatalysts from uncultured microorganisms is rising with the advent of the metagenomic approach. Therefore, metagenomic libraries should be useful for screening novel thermostable enzymes, including esterases, but no such libraries have been reported yet from thermal environmental soils with land surface temperature $82^{\circ} \mathrm{C}$ from Turban Basin in China.

In this library of 21,000 clones, 3 blue color transformants were initially selected with the esterase activity in $\mathrm{LB}$ agar plates containing $100 \mu \mathrm{M} \mathrm{X}$-caprylate, and further analysis determined that only one transformant hydrolyzed pyrethroids efficiently. These results showed that not all esterases are capable of degrading pyrethroids. Both the nucleotide and amino acid sequences of the Sys410 enzyme were novel, with the moderate identity between Sys410 and other esterases/lipases.

The novel pyrethroid-hydrolyzing esterase Sys410 had more than $50 \%$ activity from $25^{\circ} \mathrm{C}$ to $65^{\circ} \mathrm{C}$, and even displayed $41.4 \%$ activity at $20^{\circ} \mathrm{C}$. So Sys 410 possessed high activity at wide range of temperatures, different from other known pyrethroid-hydrolyzing esterases $[12,15,16]$. Sys 410 also exhibited thermostable property. The enzyme was very stable below $45^{\circ} \mathrm{C}$. After $12 \mathrm{~h}$ of 


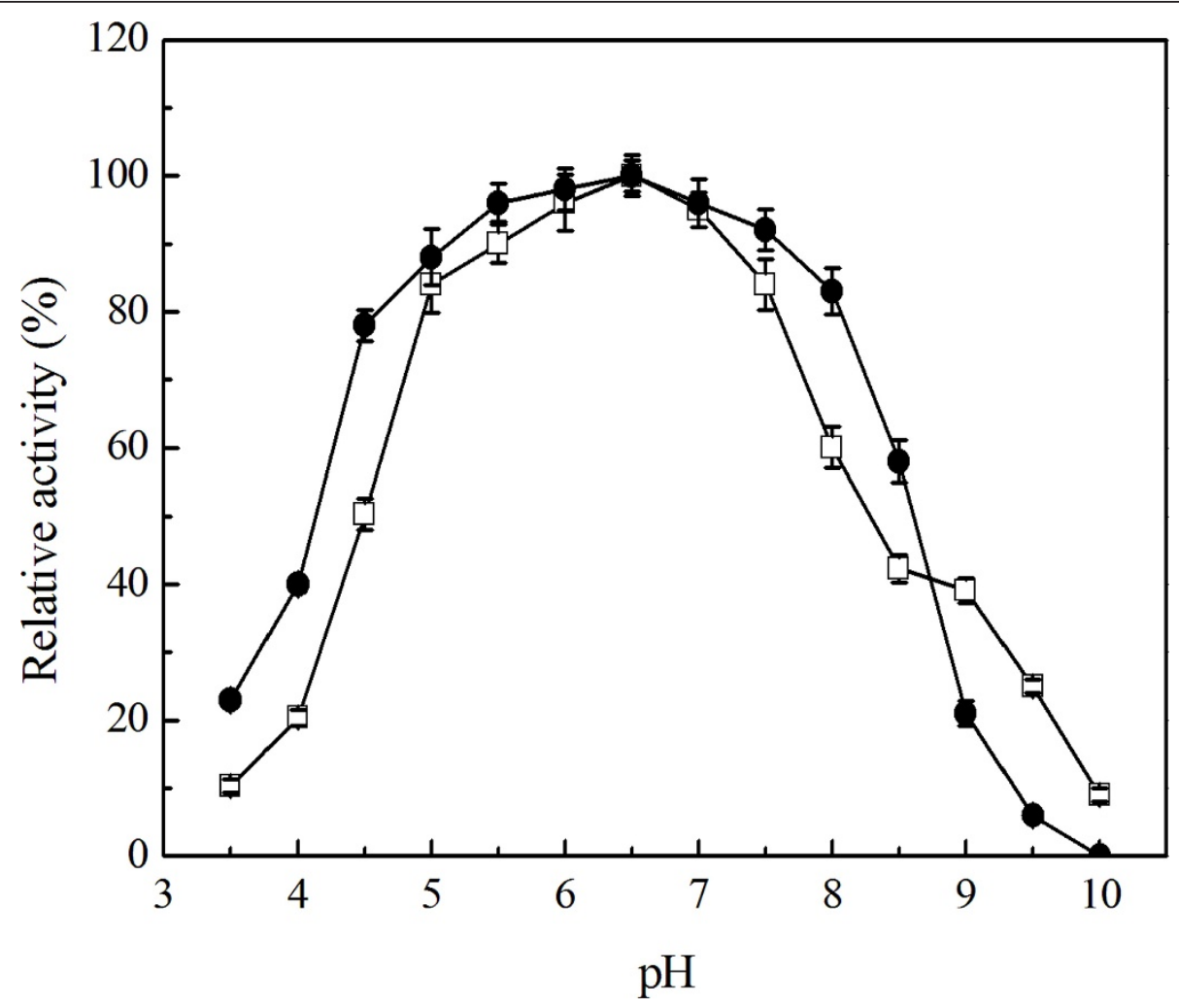

Figure 4 Effect of pH on activity $(\bullet)$ and stability $(\bullet)$ of recombinant Sys410. The purified enzyme was preincubated in different buffers for 12 hours at $30^{\circ} \mathrm{C}$.

incubation at $45^{\circ} \mathrm{C}$, it remained $85.4 \%$ activity. Sys 410 had half-lives of approximately $6 \mathrm{~h}$ and $10 \mathrm{~h}$ at $50^{\circ} \mathrm{C}$ and $55^{\circ} \mathrm{C}$, respectively. Interestingly, even incubating at $60^{\circ} \mathrm{C}$ for $1 \mathrm{~h}$, it still retained as much as $67.2 \%$ of its total activity, and then dropped dramatically, which was different from PytH with $55 \%$ residual activity at $60^{\circ} \mathrm{C}$ for $1 \mathrm{~h}[15,16]$. The residual activity was $94.1 \%$ and $68.3 \%$ after incubation $4{ }^{\circ} \mathrm{C}$ and $25^{\circ} \mathrm{C}$ for 10 weeks, respectively, which indicated that Sys 410 displayed high storage stability. These results above showed that Sys410 was the most thermostable one of the pyrethroid-hydrolyzing esterases studied before and more suitable for application.

Generally, there is a negative correlation between $\mathrm{Km}$ and $k_{\text {cat }}$ values for one enzyme toward different substrates. A low $\mathrm{Km}$ value for a substrate indicates positive affinity for the enzyme, followed with higher catalytic activity and consequently a higher $k_{\text {cat }}$ value [28].
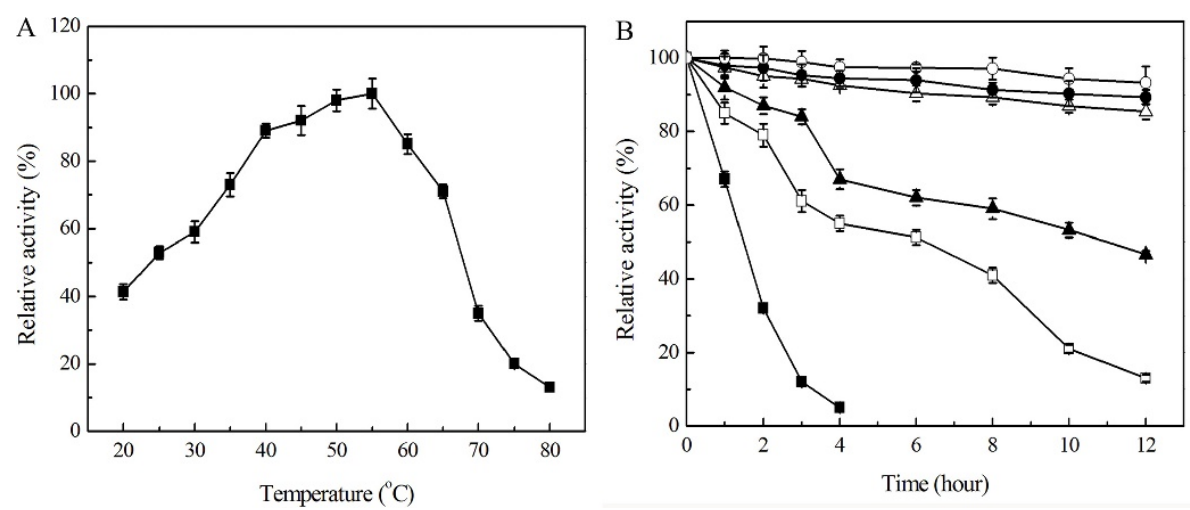

Figure 5 Effect of temperature on activity (A) and stability (B) of recombinant Sys410. The purified enzyme was preincubated at $35^{\circ} \mathrm{C}(0)$, $40^{\circ} \mathrm{C}(\bullet), 45^{\circ} \mathrm{C}(\Delta), 50^{\circ} \mathrm{C}(\boldsymbol{\Delta}), 55^{\circ} \mathrm{C}($ () $), 60^{\circ} \mathrm{C}(\bullet)$ for 12 hours. 


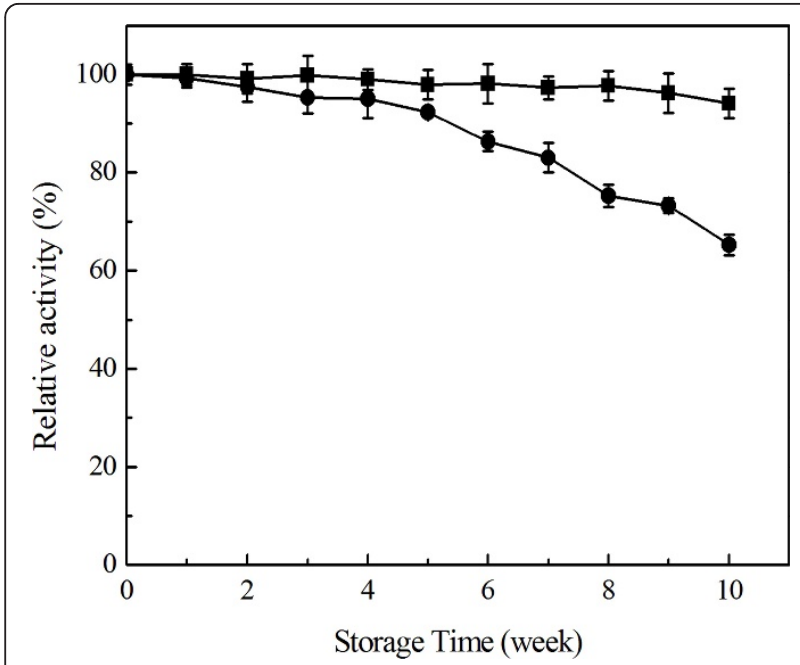

Figure 6 The storage stability of recombinant Sys 410 at $4^{\circ} \mathrm{C}(-)$ and $25^{\circ} \mathrm{C}(\bullet)$

Sys410 showed a specific preference for $\rho$-nitrophenyl acetate to other substrates, which had the lowest $\mathrm{Km}$ value $(14.1 \mu \mathrm{M})$ and highest $k_{\text {cat }}$ value $\left(289.1 \mathrm{~S}^{-1}\right)$. Presumably the structure of $\rho$-nitrophenyl acetate is closer to the natural substrate of Sys 410 .

Sys410 efficiently degraded cyhalothrin, cypermethrin, sumicidin, deltamethrin under assay conditions of $37^{\circ} \mathrm{C}$ for $15 \mathrm{~min}$, with exceeding 95\% hydrolysis rate. Therefore, the pyrethroid-hydrolyzing esterase was capable of hydrolyzing a relatively wide range of compounds with similar chemical linkage at normal temperatures, which suggested that it possessed broader substrate specificities. This feature was similar to the pyrethroid hydrolases $[15,16,18]$, while Sys410 displayed higher hydrolysis rate. However, this observation did not quite agree with data reported by Stok et al. [17].

\section{Conclusion}

Due to the importance of discovering new biotechnology products to deal with pyrethroid residues, we identified a

Table 1 Kinetic characterization of recombinant Pye843

\begin{tabular}{|c|c|c|c|}
\hline Substrates & $K \mathrm{~m}(\mu \mathrm{M})$ & $k_{\text {cat }}\left(\mathrm{S}^{-1}\right)$ & $\begin{array}{c}\text { Enzyme activity (U/ } \\
\mathrm{mg})\end{array}$ \\
\hline$\rho$-nitrophenyl acetate & $14.1 \pm 3.2$ & $\begin{array}{c}289.1 \pm \\
3.0\end{array}$ & $772.9 \pm 3.4$ \\
\hline$\rho$-nitrophenyl butyrate & $31.6 \pm 4.0$ & $\begin{array}{c}163.3 \pm \\
6.2\end{array}$ & $408.3 \pm 9.2$ \\
\hline $\begin{array}{l}\rho \text {-nitrophenyl } \\
\text { caprylate }\end{array}$ & $33.2 \pm 2.1$ & $\begin{array}{c}149.7 \pm \\
8.3\end{array}$ & $388.6 \pm 5.4$ \\
\hline$\rho$-nitrophenyl caproate & $57.6 \pm 1.9$ & $88.9 \pm 3.5$ & $115.7 \pm 4.3$ \\
\hline $\begin{array}{l}\rho \text {-nitrophenyl } \\
\text { decanoate }\end{array}$ & $99.7 \pm 9.3$ & $69.1 \pm 2.2$ & $56.9 \pm 3.2$ \\
\hline$\rho$-nitrophenyl laurate & $\begin{array}{c}130.9 \pm \\
7.2\end{array}$ & $49.1 \pm 6.6$ & $34.5 \pm 2.1$ \\
\hline
\end{tabular}

novel pyrethroid-hydrolyzing enzyme Sys410 belonging to familyV esterases/lipases with activity-based functional screening from Turban Basin metagenomic library. The soil has unique environmental characteristics with land surface temperature $82^{\circ} \mathrm{C}$ for a certain period. This is the first report to construct metagenomic libraries from Turban Basin to obtain the thermostable pyrethroid-hydrolyzing enzyme. The recombinant Sys 410 with broad substrate specificities and high activity was the most thermostable one of the pyrethroid-hydrolyzing esterases studied before, which was necessary to fulfill the practical requirements of bioremediation to enable its use in situ for detoxification of pyrethroids. Further studies will supply important data, such as high density fermentation, for future application of the enzyme for promising environmental protection and food security.

\section{Materials and methods}

\section{Chemicals and reagents}

Cyhalothrin (98\%), cypermethrin (98\%), sumicidin (98\%), deltamethrin (98\%) were kindly provided by Zhong Shan Pesticide Factory (Guang dong, China). All $\rho$-nitrophenyl esters were purchased from Sigma. All other chemicals and reagents were of analytical grade and were purchased from commercial sources, unless otherwise stated.

\section{Bacterial strains and plasmids}

E. coli TOP10 was used as the host for gene cloning and E. coli BL21 (DE3) (Novagen, Madison, USA) for protein expression. The pUC118 (TaKaRa, Dalian, China) and pET-28a (+) (Novagen, Madison, WI, USA) were used to construct metagenomic libraries and express the target protein, respectively. E. coli transformants were grown at $37^{\circ} \mathrm{C}$ in Luria-Bertani (LB) broth with appropriate antibiotics.

\section{DNA extraction from environmental samples}

The topsoil samples (5 to $10 \mathrm{~cm}$ ) from Turban Basin were used for the experiments. Samples were collected and stored at $-80^{\circ} \mathrm{C}$ until the DNA extraction was performed. The total DNA was extracted based on a method described previously [38]. Routine DNA manipulations were carried out according to standard techniques. BamHI, EcoRI, T4 DNA ligase and DNA polymerase were purchased from TaKaRa (Dalian, China). Each enzyme was used according to the recommendations of the manufacturer. Plasmids were prepared from E. coli by using E.Z. N.A Plasmid Mini Kit. DNA fragments were isolated from agarose gels by using E.Z.N.A Gel Extraction Kit.

\section{Screening for pyrethroid-hydrolyzing esterases from a metagenomic library and gene anlysis}

The purified DNA was partially digested with BamHI. DNA fragments of 2.5-10 kb were ligated into BamHI- 


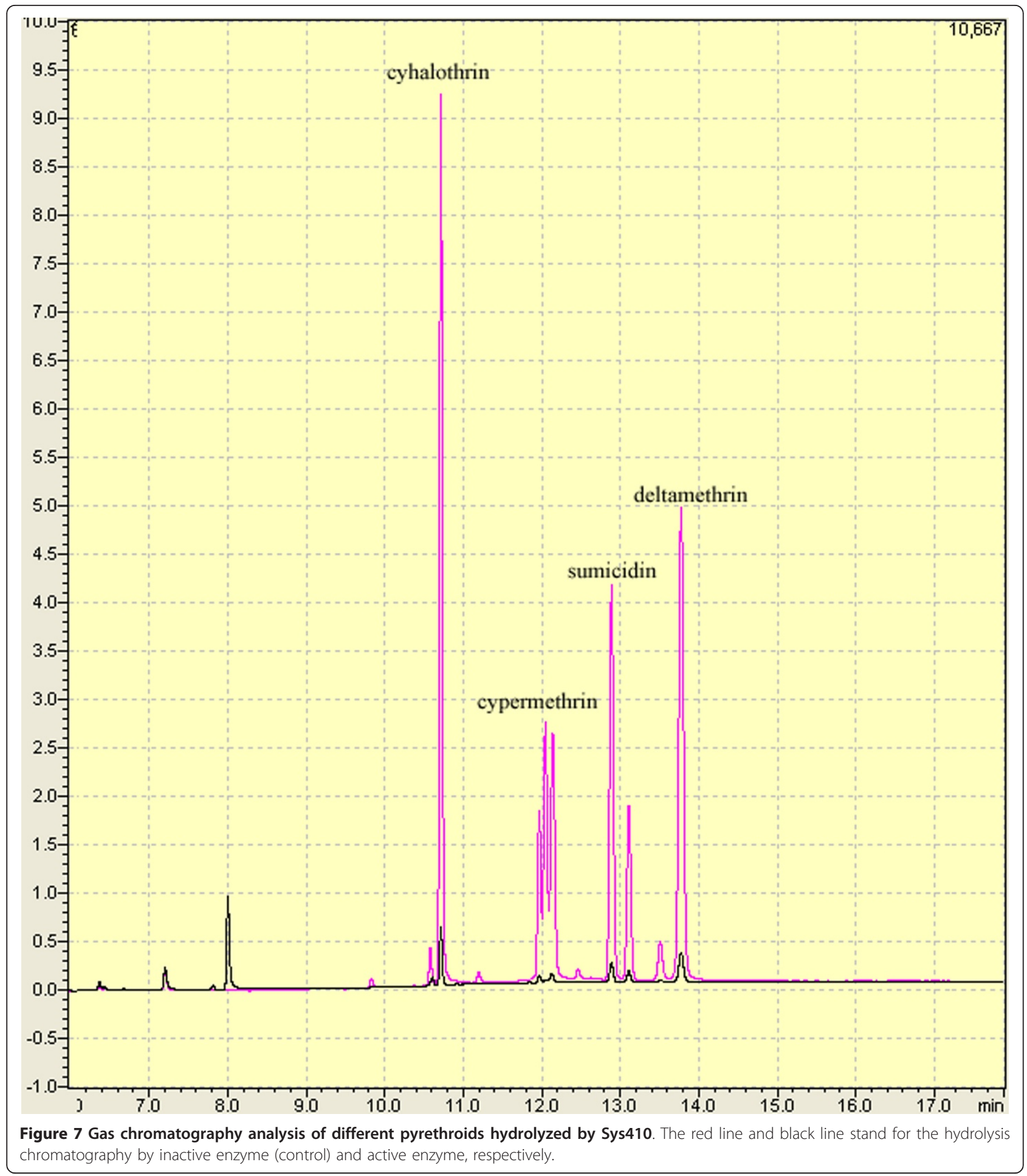

digested pUC118, and the ligated products were transformed into E. coli TOP10. The transformed cells were plated onto LB agar plates containing $50 \mu \mathrm{g} / \mathrm{mL}$ ampicillin, $0.5 \mathrm{mM}$ isopropyl- $\beta$-D-thiogalactopyranoside (IPTG) and $100 \mu \mathrm{M}$ 5-bromo-4-chloro-3-indolyl caprylate (Xcaprylate). After incubation at $37^{\circ} \mathrm{C}$ for $24 \mathrm{~h}$, clones with blue color were selected. Then clones with blue color were further tested for the ability to hydrolyze hydrolyze pyrethroids confirmed by gas chromatography analysis. Only one transformant with pyrethroid-hydrolyzing activity was obtained. Then the recombinant plasmid (pUC3) was sequenced on ABI 377 DNA 
sequencer. Sequence manipulation, open reading frame (ORF) searches, and multiple alignments among similar enzymes were conducted with Clustal W software. Database homology search was performed with BLAST program provided by NCBI. The conserved patterns of discrete amino acid sequences related enzymes were analyzed by Clustal W program.

\section{Cloning, expression and purification of pyrethroid- hydrolyzing esterase}

The putative esterase gene was amplified by PCR with the pUC118-sys 410 as template using primers which contained restriction enzyme sites BamHI and EcoRI. Amplified DNA was digested by BamHI/EcoRI, ligated into pET-28a (+) which was linearized by BamHI/ EcoRI, then transformed into E. coli BL21 (DE3) cells. $E$. coli cells transformed with this plasmid were plated onto LB agar containing $50 \mu \mathrm{g} / \mathrm{mL}$ kanamycin. Transformed cells were grown in a $250 \mathrm{~mL}$ flask containing $50 \mathrm{~mL}$ of $\mathrm{LB}(50 \mu \mathrm{g} / \mathrm{mL}$ kanamycin $)$ at $37^{\circ} \mathrm{C}$ until the cell concentration reached $\mathrm{OD}_{600}$ of 1.0, then induced with $0.6 \mathrm{mM}$ IPTG. After incubation at $37^{\circ} \mathrm{C}$ for $8 \mathrm{~h}$ with shaking at $220 \mathrm{rpm}$, cells were harvested by centrifugation $(6000 \mathrm{~g}, 10 \mathrm{~min})$ at $4^{\circ} \mathrm{C}$ and suspended in binding buffer $(0.5 \mathrm{M} \mathrm{NaCl}, 5 \mathrm{mM}$ imidazole, $20 \mathrm{mM}$ Tris- $\mathrm{HCl}, \mathrm{pH}$ 7.9). The cells were disrupted by sonication, and the supernatant was collected by centrifugation $(13000 \mathrm{~g}, 10 \mathrm{~min})$ at $4^{\circ} \mathrm{C}$. The sample was loaded onto a Ni-NTA His-Bind column pre-equilibrated with binding buffer. Then the column was washed with binding buffer and washing buffer $(0.5 \mathrm{M} \mathrm{NaCl}, 60$ $\mathrm{mM}$ imidazole, $20 \mathrm{mM}$ Tris- $\mathrm{HCl}, \mathrm{pH}$ 7.9). Finally, the bound protein was eluted with eluting buffer $(1 \mathrm{M}$ imidazole, $0.5 \mathrm{M} \mathrm{NaCl}, 20 \mathrm{mM}$ Tris- $\mathrm{HCl}$, pH 7.9). The fractions containing the recombinant protein Sys410 were collected and stored at $-20^{\circ} \mathrm{C}$.

\section{Determination of molecular mass}

The molecular mass of the denatured protein was determined by sodium dodecyl sulfate-polyacrylamide gel electrophoresis (SDS-PAGE). 12\% SDS-PAGE was prepared by the method of Laemmli [39]. Proteins were stained with Coomassie brilliant blue G-250. The molecular mass of the enzyme subunit was estimated using protein marker as standards, Rabbit muscle phosphorylase B (97,200 Da), bovine serum albumin $(66,409 \mathrm{Da})$, ovalbumin $(44,287 \mathrm{Da})$, carbonic anhydrase $(29,000 \mathrm{Da})$, Soybean Trypsin Inhibitor (20,100 Da), Hen egg white Lysozyme (14,300 Da).

\section{Effect of $\mathrm{pH}$ and temperature on activity and stability of recombinant Sys 410}

The optimum pH of recombinant Sys410 was measured using $\rho$-nitrophenyl acetate as a substrate at $40^{\circ} \mathrm{C}$. The buffers (the final concentration of $50 \mathrm{mM}$ ) used for the measurement were as below: citric acid- $\mathrm{NaOH}$ buffer (pH 3.5-5.5); potassium phosphate buffer ( $\mathrm{pH}$ 5.0-7.0); Tris- $\mathrm{HCl}$ buffer ( $\mathrm{pH}$ 6.5-9.0), glycine- $\mathrm{NaOH}$ buffer $(\mathrm{pH}$ 8.5-10.0). Overlapping $\mathrm{pH}$ values were used to verify that there were no buffer effects on substrate hydrolysis. The $\mathrm{pH}$ stability was tested after incubation of the purified enzyme for $24 \mathrm{~h}$ at $30^{\circ} \mathrm{C}$ in the above different buffers. The optimum temperature was determined analogously by measuring esterase activity at $\mathrm{pH} 6.5$ in the temperature range of $20-80^{\circ} \mathrm{C}$. Temperature stability was measured by preincubation of the purified enzyme for different time in $50 \mathrm{mM}$ potassium phosphate buffer $(\mathrm{pH}$ $6.5)$ at different temperatures. The storage stability of the recombinant enzyme Sys 410 was determined by preincubation of the purified enzyme for 10 weeks in $50 \mathrm{mM}$ potassium phosphate buffer $(\mathrm{pH} 6.5)$ at $4^{\circ} \mathrm{C}$ and $25^{\circ} \mathrm{C}$.

\section{Analysis of Sys 410 activity}

The esterase activity against $\rho$-nitrophenyl acetate ( $\rho N P E)$ was determined by measuring the amount of $\rho$ nitrophenol released by esterase-catalyzed hydrolysis. The substrate ( $\rho \mathrm{NPE})(3 \mathrm{mg}$ ) with final concentration of $0.3 \mathrm{mg} / \mathrm{mL}$ was dissolved in $1 \mathrm{~mL}$ of isopropanol and mixed with $9 \mathrm{~mL}$ of $50 \mathrm{mM}$ potassium phosphate buffer ( $\mathrm{pH}$ 6.5) containing gum arabic $(0.1 \%, \mathrm{w} / \mathrm{v})$ and Triton $\mathrm{X}-100(0.6 \%, \mathrm{w} / \mathrm{v})$. The hydrolysis of substrate was performed at $55^{\circ} \mathrm{C}$ for $5 \mathrm{~min}$ in $50 \mathrm{mM}$ potassium phosphate buffer ( $\mathrm{pH}$ 6.5). The production of $\rho$-nitrophenol was monitored spectrophotometrically at $405 \mathrm{~nm}$ by Labsystems Dragon Wellscan MK3. One unit of enzyme activity was defined as the amount of enzyme that produced $1 \mu \mathrm{mol}$ of $\rho$-nitrophenol per minute under these conditions. In each measurement, the effect of nonenzymatic hydrolysis of substrates was taken into consideration and subtracted from the value measured when the enzyme was added.

\section{Determination of substrate specificity and kinetic parameters}

Substrate specificity against different $\rho$-nitrophenyl esters was determined using $\rho$-nitrophenyl acetate $(\mathrm{C} 2)$, $\rho$-nitrophenyl butyrate $(\mathrm{C} 4), \rho$-nitrophenyl caprylate (C6), $\rho$-nitrophenyl caproate (C8), $\rho$-nitrophenyl decanoate (C10), $\rho$-nitrophenyl laurate $(\mathrm{C} 12)$ as substrates, the activity was then measured described above at the final substrate concentration of $0.3 \mathrm{mg} / \mathrm{mL}$ separately.

The purified Sys410 was incubated with various concentrations of $\rho$-nitrophenyl acetate. The final concentration ranged from $1.0 \mathrm{mM}$ to $10.0 \mathrm{mM}$ in potassium phosphate buffer (6.5). The kinetic constants were calculated by fitting the initial rate data into the MichaelisMenten equation using the GraFit software (version 6; Erithacus Software Ltd., Horley, UK). 


\section{Gas chromatography analysis of different pyrethroids degradation by Sys 410}

Sys410 was tested for hydrolysis of cyhalothrin, cypermethrin, sumicidin, deltamethrin by Gas chromatography. The enzyme samples $(24 \mu \mathrm{g})$ with $5 \mathrm{mg} / \mathrm{mL}$ substrates in $50 \mathrm{mM}$ potassium phosphate buffer $(\mathrm{pH} 6.5)$ were incubated at $37^{\circ} \mathrm{C}$ for $15 \mathrm{~min}$. Aliquots $(1 \mu \mathrm{L})$ of the reaction mixtures were loaded onto a Gas chromatography system (GC-2010, Shimadzu Corporation, Japan) with ECD Detector using RestekRTX-5 column $(30 \mathrm{~m} \times 0.25 \mathrm{~mm} \times$ $0.25 \mu \mathrm{m})$. The column flow was $2 \mathrm{~mL} / \mathrm{min}$. The column was set at $150^{\circ} \mathrm{C}$ for $1 \mathrm{~min}$, and heated to $270^{\circ} \mathrm{C}$ at $30^{\circ} \mathrm{C} /$ $\mathrm{min}^{-1}$. The temperature of ECD Detector was $300^{\circ} \mathrm{C}$. The electric current was $1 \mathrm{nA}$. In each measurement, the effect of nonenzymatic hydrolysis of substrates was taken into consideration and subtracted from the value measured when the enzyme was added.

\section{Nucleotide sequence accession number}

The nucleotide sequence data reported here have been submitted to the nucleotide sequence databases under accession number (JQ272178).

\section{Acknowledgements}

We are grateful to National Natural Science Foundation of China (31170117), National marine research special funds for public welfare projects of China (201205020); Major Science \& Technology Projects of Guangdong Province, China (2011A080403006); the Science and Technology Plan Project of Guangdong province (2010A080403005); the National High Technology Research and Development Program of China (863 Program) (2007AA10Z308) and the Research (Innovative) Fund of Laboratory Sun Yatsen University (YJ201027) for their financial support.

\section{Author details}

${ }^{1}$ School of life sciences, Sun Yat-sen University, Guangzhou 510275, P. R. China. ${ }^{2}$ Guangzhou Liby Enterprise CO., LTD, Guangzhou 510170, P. R. China.

\section{Authors' contributions}

XJF: have performed construction of metagenomic library, gene cloning and expression in E. coli, and enzyme characterization. XLL: have collected samples in Turban Basin. RH: have extracted DNA from soil samples. YHL: have conceived the study, designed and supervised the experiments, drafted and revised the manuscript. All authors have read and approved the manuscript.

\section{Competing interests}

The authors declare that they have no competing interests.

Received: 28 December 2011 Accepted: 13 March 2012 Published: 13 March 2012

\section{References}

1. George N, Kalyanasundaram M: Chemistry of synthetic pyrethroid insecticides -some recent advances. J Sci Ind Res 1994, 53:933-945.

2. Ross MK, Borazjani A, Edwards CC, Potter PM: Hydrolytic metabolism of pyrethroids by human and other mammalian carboxylesterases. Biochem Pharmacol 2006, 71:657-669.

3. Lee SJ, Gan JY, Kabashima J: Recovery of synthetic pyrethroids in water samples during storage and extraction. J Agric Food Chem 2002 50:7194-7198.

4. Liu WP, Gan JY, Schlenk D, Jury WA: Enantioselectivity in environmental safety of current chiral insecticides. Proc Natl Acad Sci 2005, 102:701-706
5. Katsuda Y: Development of and future prospects for pyrethroid chemistry. J Pestic Sci 1999, 55:775-782.

6. Park EK, Kim JH, Gee SJ, Watanabe T, Ahn KC, Hammock BD: Determination of pyrethroid residues in agricultural products by an enzyme-linked immunosorbent assay. J Agric Food Chem 2004, 52:5572-5576.

7. Jolly AL, Graves JB, Avault JW, Koonce KL: Effects of a new insecticide on aquatic animals. Louisiana Agriculture 1978, 21(2):3-4

8. Zabel TF, Seager J, Oakley SD: Proposed environmental quality standards for List II substances in water Marlow, Buckinghamshire, United Kingdom: Water Research Centre; 1988.

9. Phale PS, Basu A, Majhi PD, Deveryshetty J, Vamsee-Krishna C, Shrivastava R: Metabolic diversity in bacterial degradation of aromatic compounds. OMICS - a Journal of Integrative Biology 2007, 11:252-279.

10. Crow JA, Borazjani A, Potter PM, Ross MK: Hydrolysis of pyrethroids by human and rat tissues: examination of intestinal, liver and serum carboxylesterases. Toxicol Appl Pharmacol 2007, 221:1-12.

11. Chiang SW, Sun CN: Purification and characterization of carboxylesterases of a rice green leafhopper Nephotettix cincticep uhler. Pestic Biochem Physiol 1996, 54:181-189.

12. Maloney SE, Maule A, Smith AR: Purification and preliminary characterization of permethrinase from a pyrethroid-transforming strain of Bacillus cereu. Appl Environ Microbiol 1993, 59:2007-2013.

13. Bornscheuer UT: Microbial carboxyl esterases: classification, properties and application in biocatalysis. FEMS Microbiol Rev 2002, 26:73-81.

14. Tőke ER, Nagy V, Recseg K, Szakács G, Poppe L: Production and application of novel sterol esterases from Aspergillu strains by solid state fermentation. J Am Oil Chem Soc 2007, 84:907-915.

15. Li G, Wang K, Liu YH: Molecular cloning and characterization of a novel pyrethroid-hydrolyzing esterase originating from the metagenome. Microb Cell Fact 2008, 7:1-10.

16. Wang BZ, Guo P, Hang BJ, Li L, He J, Li SP: Cloning of a novel pyrethroidhydrolyzing carboxylesterase gene from sphingobium sp. strain jz-1 and characterization of the gene product. Appl Environ Microbiol 2009, 75(17):5496-5500.

17. Stok JE, Huang HZ, Jones PD, Wheelock CE, Morisseau C, Hammock BD: Identification, expression, and purification of a pyrethroid-hydrolyzing carboxylesterase from mouse liver microsomes. J Biol Chem 2004, 279:29863-29869.

18. Liang WQ, Wang ZY, Li H, Wu PC, Hu JM, Luo N, Cao LX, Liu YH: Purification and characterization of a novel pyrethroid hydrolase from Aspergillus nige ZD11. J Agric Food Chem 2005, 53:7415-7420.

19. Haki GD, Rakshit SK: Developments in industrially important thermostable enzymes: a review. Bioresour Technol 2003, 89:17-34

20. Lasa I, Berenguer J: Thermophilic enzymes and their biotechnological potential. Microbiologia 1993, 9:77-89.

21. Handelsman J: Metagenomics: application of genomics to uncultured microorganisms. Microbiol Mol Biol Rev 2004, 68:669-685.

22. Sleator RD, Shortall C, Hill C: Metagenomics. Lett Appl Microbiol 2008, 47:361-366.

23. Lorenz P, Eck J: Metagenomics and industrial applications. Nat Rev Microbiol 2005, 3:510-516.

24. Jeon JH, Kim JT, Kim YJ, Kim HK, Lee HS, Kang SG, Kim SJ, Lee JH: Cloning and characterization of a new cold-active lipase from a deep-sea sediment metagenome. Appl Microbiol Biotechnol 2009, 81(5):865-874.

25. Ranjan R, Grover A, Kapardar RK, Sharma R: Isolation of novel lipolytic genes from uncultured bacteria of pond water. Biochem Biophys Res Commun 2005, 335:57-65.

26. Rhee JK, Ahn DG, Kim YG, Oh JW: New thermophilic and thermostable esterase with sequence similarity to the hormonesensitive lipase family, cloned from a metagenomic library. Appl Environ Microbiol 2005, 71:817-825.

27. Rhee JK, Ahn DG, Kim YG, Oh JW: New thermophilic and thermostable esterase with sequence similarity to the hormone-sensitive lipase family, cloned from a metagenomic library. Appl Environ Microbiol 2005, 71(2):817-825.

28. Glogauer A, Martini V, Faoro H, Couto G, Müller-Santos M, Monteiro R, Mitchell D, de Souza E, Pedrosa F, Krieger N: Identification and characterization of a new true lipase isolated through metagenomic approach. Microb Cell Fact 2011, 10:54.

29. Glogauer A, Martini V, Faoro H, Couto G, Müller-Santos M, Monteiro R Mitchell D, de Souza E, Pedrosa F, Krieger N: Identification and 
characterization of a new true lipase isolated through metagenomic approach. Microbial Cell Factories 2011, 10:54.

30. Wei Y, Schottel JL, Derewenda U, Swenson L, Patkar S, Derewenda ZS: A novel variant of the catalytic triad in the Streptomyces scabies esterase. Nat Struct Mol Biol 1995, 2:218-223.

31. Arpigny JL, Jaeger KE: Bacterial lipolytic enzymes: classification and properties. Biochem J 1999, 343:177-183.

32. Jiang $C$, Wu B: Molecular cloning and functional characterization of a novel decarboxylase from uncultured microorganisms. Biochem Biophys Res Commun 2007, 357:421-426.

33. Amann Rl, Ludwig W, Schleifer KH: Phylogenetic identification and in-situ detection of individual microbial cells without cultivation. Microbiol Rev 1995, 59(1):143-169.

34. Rappé MS, Giovannoni SJ: The uncultured microbial majority. Annu Rev Microbiol 2003, 57:369-394.

35. Lee SW, Won K, Lim HK, Kim JC, Choi GJ, Cho KY: Screening for novel lipolytic enzymes from uncultured soil microorganisms. Appl Microbiol Biotechnol 2004, 65(6):720-726.

36. Elend C, Schmeisser C, Hoebenreich H, Steele HL, Streit WR: Isolation and characterization of a metagenome-derived and cold-active lipase with high stereospecificity for (R)-ibuprofen esters. J Biotechnol 2007, 130(4):370-377.

37. Elend C, Schmeisser C, Leggewie C, Babiak P, Carballeira JD, Steele HL, Reymond JL, Jaeger KE, Streit WR: Isolation and biochemical characterization of two novel metagenome-derived esterases. Appl Environ Microbiol 2006, 72(5):3637-3645.

38. Zhou J, Bruns MA, Tiedje JM: DNA recovery from soils of diverse composition. Appl Environ Microbiol 1996, 62:316-322.

39. Laemmli UK: Cleavage of structural proteins during the assembly of the head of bacteriophage T4. Nature (London) 1970, 227:680-685.

doi:10.1186/1475-2859-11-33

Cite this article as: Fan et al: Identification and characterization of a novel thermostable pyrethroid-hydrolyzing enzyme isolated through metagenomic approach. Microbial Cell Factories 2012 11:33.

\section{Submit your next manuscript to BioMed Central} and take full advantage of:

- Convenient online submission

- Thorough peer review

- No space constraints or color figure charges

- Immediate publication on acceptance

- Inclusion in PubMed, CAS, Scopus and Google Scholar

- Research which is freely available for redistribution

Submit your manuscript at www.biomedcentral.com/submit
Biomed Central 